\title{
Control of Carrot Seed-Borne Pathogens by Aromatic Plants Distillates ${ }^{\dagger}$
}

\author{
Simona Lukošiūtè *, Neringa Rasiukevičiūtè and Alma Valiuškaitè \\ Laboratory of Plant Protection, Institute of Horticulture, Lithuanian Research Centre for Agriculture and \\ Forestry, LT-54333 Babtai, Kaunas District, Lithuania; neringa.rasiukeviciute@lammc.lt (N.R.); \\ alma.valiuskaite@lammc.lt (A.V.) \\ * Correspondence: simona.lukosiute@lammc.lt \\ + Presented at the 1st International Electronic Conference on Plant Science, 1-15 December 2020; Available \\ online: https://iecps2020.sciforum.net/.
}

Published: 30 November 2020

\begin{abstract}
Global warming, pollution problems, and the demand for sustainable food production forced farmers and scientists to search for new solutions in biological plant protection. The usage of natural renewable sources around us seems to be an alternative. Compounds isolated from plants and distinguished with antifungal properties can be used to protect vegetables from the seed-borne pathogens. The study aimed to elucidate the ability of Juniperus communis L., Hyssopus officinalis L. and Thymus vulgaris L. essential oils to control carrot seedborne pathogen Alternaria spp. The agar-plate method was used for carrot seeds infestation with micromycetes. Essential oils extracted from common juniper, hyssop and thyme then separately mixed with potato dextrose agar media at different concentrations and the antifungal activity of each oil tested in vitro. The results revealed that the T. vulgaris essential oil (200-1000 $\left.\mu \mathrm{L} \mathrm{L}^{-1}\right)$ significantly inhibited Alternaria spp. growth. The H. officinalis essential oil promoted seed-borne pathogens growth the second and fifth days of the evaluation compared to control; however, the concentration of $400 \mu \mathrm{L} \mathrm{L}^{-1}$ showed little suppression of micromycete development 7 days after inoculation. The in vitro experiments indicated that $600 \mu \mathrm{L} \mathrm{L}^{-1}$ of $J$. communis essential oil could control seed-borne pathogen viability. Overall, thyme essential oil expressed a high potential for application in biofungicides formulations.
\end{abstract}

Keywords: Daucus sativus Röhl.; essential oils; thyme; hyssop; common juniper; Alternaria spp.; suppression

\section{Introduction}

Carrot (Daucus carota L.) is one of the most crucial root vegetables in the family Apiaceae, which is cultivated worldwide. Current studies are mainly focused on nutrient content, breeding, cultivation, increasing yield, tissue culture, and regulating carotenoid synthesis [1-3]. However, very often, the cultivation of vegetables is faced with various diseases caused by microorganisms living in the soil. Moreover, the quality of the seeds themselves and contamination with micromycetes are rarely considered. Seeds take a massive part of crop production and are vital for plant associations with microorganisms. Seed-borne pathogens infect seeds and cause the growth disorders of infected crops. The Alternaria genus is well known as causal of destructive diseases of carrots, parsnips, celery, and parsley with symptoms such as seedling death, petiole base blackening, leaf death, black rot of the crown, and stored roots [4]. In addition to these features, this pathogen also adversely affects seed germination [5]. Seed-borne diseases can be managed by various strategies including chemical, cultural and technological methods [6]. In the past few decades, chemicals are widely used for treatment as a potent approach toward disease control, and the usage of chemical fungicides added further possibilities to it [7-10]. Nevertheless, pesticides pose distinct risks to the organic production of carrot seeds, because the use of effective chemical fungicides to resist foliar and leaf blight is not allowed. Additionally, their non-target environmental impact like the development of pathogen 
resistance, hazards to human health and other living organisms, pesticide residues in the environment, and agricultural products has led to the search for alternative methods to control and make agriculture more sustainable [11,12].

Medicinal and aromatic plants are natural renewable sources full of bioactive compounds. Essential oils extracted from them are widely studied for their antioxidant, antibacterial, antifungal, immunomodulatory, and also anti-inflammatory properties [13-16]. Due to these features, they can be applied to innovative plant protection, for example, clove, mint, and oregano essential oils inhibited the growth of fungal species belonging to Acremonium, Alternaria, Arhrobotrys, Aspergillus, Cladosporium, Epicoccum, Fusarium, Penicillium, Rhizopus, Trichoderma and Ulocladium genera on wheat seeds [16]. High antifungal effectiveness of palmarosa, lemongrass, and geranium essential oils have already been observed against seed-borne fungi Cochliobolus miyabeanus Ito \& Kuribayashi and Fusarium verticillioides (Sacc.) Nirenberg of rice [18]. The literature review revealed, that there has been comparatively less research regarding environmentally friendly ways to prevent fungal infections of carrot seeds, especially, it is a lack of studies on the antifungal activity of common juniper, hyssop, and thyme essential oils against Alternaria spp. Therefore it was aimed to evaluate the ability of essential oils of Juniperus communis L., Hyssopus officinalis L. and Thymus vulgaris L. to control carrot seed-borne pathogen Alternaria spp.

\section{Experiments}

\subsection{Seeds Preparation}

For the research, carrot seeds cultivar 'Svalia' was used, which were obtained from the Lithuanian Research Centre for Agriculture and Forestry Institute of Horticulture (LAMMC IH) Department of Vegetable Breeding and Technology. The disinfection of vegetable seeds was done by soaking them in $70 \%$ ethanol for $5 \mathrm{~min}$ and then rinsing them in sterile water three times for $5 \mathrm{~min}$. After this, seeds were dried for 5-10 min in laminar flow to evaporate water from the surface of the seeds. This procedure removes extraneous microorganisms from the outside of the husk and allows to determine the internal infestation of seeds with pathogens.

\subsection{Essential Oils Production}

H. officinalis, and T. vulgaris plants were grown in the LAMMC IH experimental fields. Following the methods of essential oils extraction, the necessary essential oils (EOs) were separately isolated by hydrodistillation, in which the naturally dried plant material is boiled in water under normal atmospheric pressure for $2 \mathrm{~h}$ [19]. The EO of J. communis obtained (UAB Naujoji Barmune).

\subsection{Medium Preparation}

Potato dextrose agar (PDA) medium (Sigma-Aldrich) consisting of $4 \mathrm{~g} \mathrm{~L}^{-1}$ potato extract, $15 \mathrm{~g} \mathrm{~L}^{-1}$ agar, and $20 \mathrm{~g} \mathrm{~L}^{-1}$ dextrose was used for this study. Potato extract is a source of nutrients that promotes fungal sporulation and pigment production, and dextrose acts as a growth stimulator [20]. The medium with the acidity of $5.6 \pm 0.2$ was sterilised in a high-pressure autoclave for $20 \mathrm{~min}$ at 121 ${ }^{\circ} \mathrm{C}$. After autoclaving, different concentrations of $200,400,600,800$ and $1000 \mu \mathrm{L} \mathrm{L}^{-1}$ of each EO were added to the medium after cooling it to $45^{\circ} \mathrm{C}$, mixed and poured into sterilised Petri dishes allowing to solidify. A control treatment was without EO.

\subsection{Essential Oils Effect on Pathogens}

The research was carried out at the LAMMC IH Laboratory of Plant Protection. Using the agarplate method [21] prepared surface-sterilised carrot seeds were arranged in a square shape (5 rows and 5 columns) on each Petri dish with PDA and the appropriate concentration of EO as shown in Figure 1. 


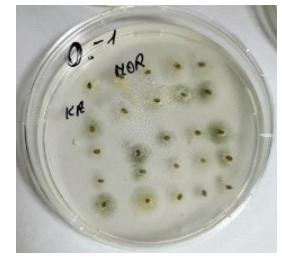

Figure 1. Arrangement of 25 carrot seeds.

Each study treatment consisted of 24 plates (4 replicates). Dishes incubated at $22 \pm 2{ }^{\circ} \mathrm{C}$ temperature in the dark for up to 10 days [22]. Seed internal disease assessment was performed after 2,5 , and 7 days. The number of fungal and bacterial colonies on the seeds was counted in each plate and the percentage of Alternaria spp. settlements in the treatment were calculated. Essential oil effect on pathogens was evaluated according to the infection rate using the formula below (1) [5]. Lower infection rate described the more effective activity to control seed-borne pathogens.

Alternaria spp. infected seeds rate $(\%)=$ Number of seeds infected by Alternaria spp. $\times$ 100/Total number of infected seeds.

Types of fungus were determined visually and microscopically based on cultural and morphological characteristics typical to the colonies $[10,23]$.

\subsection{Statistics}

Experimental data were analysed by SAS Enterprise Guide 7.1 program (SAS Institute Inc., Cary, NC, USA). Analysis of variance (ANOVA) procedure was processed. Other calculations were done using Microsoft Excel.

\section{Results}

The antifungal activity of H. officinalis, T. vulgaris and J. communis EOs was investigated on PDA under different concentrations in vitro. The incidence of Alternaria spp. under the influence of $T$. vulgaris EO is presented in Figure 2. It can be seen that the growth of seed-borne pathogen was significantly inhibited $(p<0.05)$ by all used concentrations of this EO. No fungal germs were noticed in all treatments after 2 days. Whereas in the control treatment, the spread of Alternaria spp. reached $36 \%$ of all grown fungi and bacteria after 5 days, and increased to $38 \%$ after 7 days.

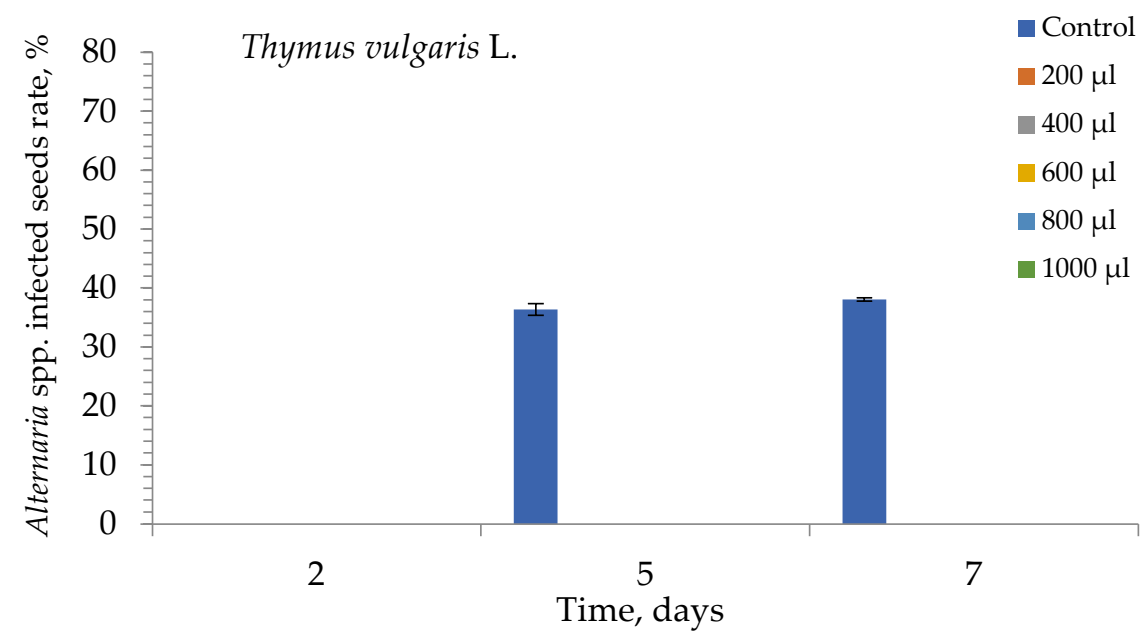

Figure 2. The seed infection with Alternaria spp. under the influence of different concentrations of $T$. vulgaris essential oil after 2,5 , and 7 days.

The incidence of Alternaria spp. on seeds under the influence of $H$. officinalis EO is presented in Figure 3. Assessment of carrot seed lesions at 400 and $1000 \mu \mathrm{L} \mathrm{L}^{-1}$ concentrations of this EO revealed 
that Alternaria spp. damaged $1 \%$ of seeds after 2 days. At the next evaluation, after 5 days, there was $39 \%$ prevalence of this fungus in the control treatment, while with all used applications of EOs it was higher: $800 \mu \mathrm{L} \mathrm{L}-1-48 \%, 400 \mu \mathrm{L} \mathrm{L}^{-1}-52 \%, 200 \mu \mathrm{L} \mathrm{L}^{-1}-63 \%, 1000 \mu \mathrm{L} \mathrm{L}^{-1}-64 \%$ and $600 \mu \mathrm{L} \mathrm{L}^{-1}-74 \%$ contaminated seeds. H. officinalis EO showed highest inhibiotion at $600 \mu \mathrm{L} \mathrm{L}^{-1}$ after 7 days, causing a decrease in the percentage of infected seeds. However, $200 \mu \mathrm{L} \mathrm{L}^{-1}, 800 \mu \mathrm{L} \mathrm{L}^{-1}$ and $1000 \mu \mathrm{L} \mathrm{L}^{-1}$ of EO did not inhibit fungal growth-the number of micromycetes increased to $75 \%, 64 \%$ and $74 \%$ respectively. Thus, H. officinalis EO even promoted the development of the fungus more than inhibited it.

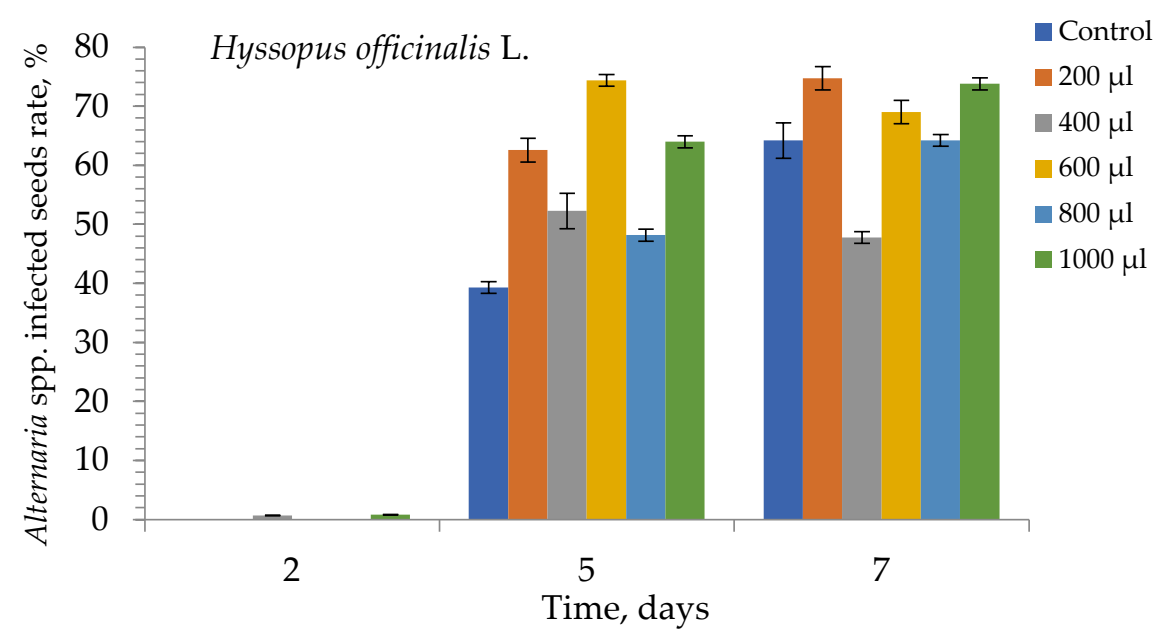

Figure 3. The seed infection with Alternaria spp. under the influence of different concentrations of hyssop essential oil after 2, 5, and 7 days.

The prevalence of Alternaria spp. under the influence of J. communis EO is presented in Figure 4. The assay revealed that $J$. communis $\mathrm{EO}$ had a weak antifungal activity against fungi of the genus Alternaria after 2 days. Still, the best effect was shown by a concentration of $600 \mu \mathrm{L} \mathrm{L}^{-1}(16 \%)$. The spread of micromycetes was slightly higher (31-32\%) with $200 \mu \mathrm{L} \mathrm{L}^{-1}$ and $600-1000 \mu \mathrm{L} \mathrm{L}^{-1}$ of $J$. communis $\mathrm{EO}$ than the controls (29\%) after 5 days. After 7 days, the number of pathogenic fungi in carrot seeds did not change significantly. Nevertheless, $400 \mu \mathrm{L} \mathrm{L}^{-1}$ of this plant distillate exhibited the best fungal incidence inhibition (22-23\%) on 5 and 7 days of the experiment.

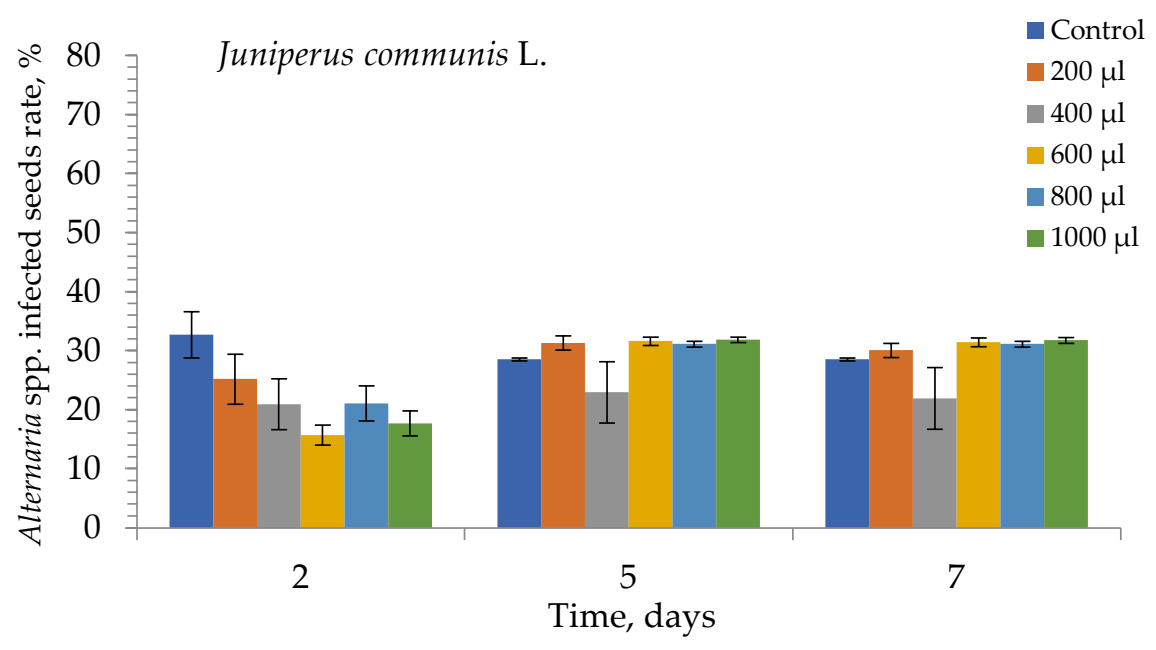

Figure 4. The seed infection with Alternaria spp. under the influence of different concentrations of common juniper essential oil after 2,5 , and 7 days. 
Analysis of data showed that these distillates had an unequal effect on the health of carrot seeds and Alternaria spp. The T. vulgaris EO (200-1000 $\left.\mu \mathrm{L} \mathrm{L}^{-1}\right)$ inhibited the growth of micromycetes most significantly, but $400 \mu \mathrm{L} \mathrm{L^{-1 }}$ of J. communis $\mathrm{EO}$ also had a modest antifungal effect.

\section{Discussion}

Green issues and potential threats to human health arising from the long-term use of chemical fungicides require innovative plant protection solutions [11,12], also, due to infections of the seeds by Alternaria spp., the germination rate decreases [5]. Thus, screening for suitable biofungicides and optimising their applications is essential. This study provided new data about in vitro inhibition effects of medicinal and aromatic plant-based substances against carrot seed-borne pathogens Alternaria spp.

The $T$. vulgaris EO concentration $200-1000 \mu \mathrm{L} \mathrm{L}^{-1}$ significantly reduced fungus incidence when it was compared to the untreated control. There are several reports about antibacterial and antifungal activities of T. vulgaris oil components and some other experiments also revealed that this oil might be effectively used to control Alternaria spp. on carrot seeds [24-27]. Dorna and Szopińska [25] using a different methodology found that the percentage of seeds free of fungi increased and the incidence of Alternaria alternata (Fr.) Keissl. in cultivar 'Flakkese 2' seeds decreased. However, the opposite effect was with the cultivar 'Amsterdam 3' seeds: T. vulgaris EO favoured the growth of Alternaria radicina Meier, Drechsler \& E.D. Eddy and Alternaria dauci (J.G. Kühn) J.W. Groves \& Skolko, but the percentage of infected seeds was only 0.5 . There is known that some microorganisms are stimulated by antimicrobial agents and use EO as a carbon energy source [26]; this may have been the case for the A. radicina examined in Dorna and Szopińska study. Koch et al. [27] confirmed the high antifungal activity of T. vulgaris EO against Alternaria species when used seeds (variety 'Laguna') were stirred for $4 \mathrm{~h}$ in $1 \%$ oil emulsion. However, the authors emphasise that due to inherent oil phytotoxicity, the choice of the optimal concentration is critical, and pre-testing is recommended. Our results contribute to the findings of Riccioni and Orzali [28], whose study showed promising prospects for a source of natural plant EOs and that T. vulgaris EO concentrations of $0.05 \%, 0.1 \%, 0.25 \%, 0.5 \%, 1 \%$ had an apparent reducing effect on $A$. dauci fungal growth in vitro.

In our study study was found out that J. communis EO exhibited the highest Alternaria spp. inhibition at $400 \mu \mathrm{L} \mathrm{L}^{-1}$. Meanwhile, investigations are determining the ability of the J. communis to inhibit the development of seed-borne and soil-borne pathogens, but no to the Alternaria genus. For example, in Zabka et al. [29] research, J. communis EO exhibited average efficacy at $1 \mu \mathrm{L} \mathrm{mL}^{-1}$ concentration on other pathogens such as Fusarium oxysporum Schlechtendahl, F. verticillioides (Sacc.) Nirenberg, Penicillium brevicompactum Dierckx, P. expansum Link, Aspergillus flavus Link and A. fumigates Fresenius, the effect on Alternaria spp. have not been studied. Nevertheless, T. vulgaris were determined as the most effective against the growth of target fungal species. Either, while screening the methanolic extract of J. communis well antimicrobial activity against the Candida albicans (C. P. Robin) Berkhout, A. niger and A. flavus fungi were observed [30]. Menghani and Sharma results revealed the maximum activity to $A$. niger and A. flavus. Additionally, this EO was effective against phytopathogenic bacteria.

Analysing the antifungal effect of $H$. officinalis EO, in our assay, it did not inhibit fungal development and even stimulated comparing to control treatment. However, Fraternale and colleagues [31] have shown significant antifungal activity against 13 strains of phytopathogenic fungi. Reports indicated that $100 \%$ inhibition for all pathogens as well as Alternaria solani Sorauer was achieved with 1400 and $1600 \mu \mathrm{L} \mathrm{mL}-1$ of oil. According to the authors, this may have been due to higher levels of active substances: pinocamphone, isopinocamphone, linalool and camphor. Based on data from other scientists, it can be assumed that too low concentrations of this oil were used. Still, there are many investigations on $\mathrm{H}$. officinalis antimicrobial features with other microorganisms, where this EO indicates undoubted prospects [32].

To conclude, EOs of J. communis, H. officinalis and T. vulgaris showed moderate ability to control the seed-borne pathogens. Results demonstrated that T. vulgaris EO had a significant reducing effect on fungal pathogens, confirming what is already reported in the literature. However, because the in 
vitro effects did not always provide a good effect for their in vivo performances, additional studies are necessary to verify the effectiveness in field conditions as seed treatment and their possible phytotoxicity on the plant or seed material. Besides T. vulgaris EO is promising against carrot seedborne pathogen Alternaria spp.

\section{Conclusions}

T. vulgaris EO concentrations of 200-1000 $\mu \mathrm{L} \mathrm{L}^{-1}$ revealed the potential to suppress the prevalence of Alternaria spp., it significantly inhibited fungal growth, while J. communis and H. officinalis EOs inhibition was dose-dependent and less powerful. T. vulgaris plant can be considered as a potential source of biofungicide to the chemicals products that are currently used to prevent and control seedborne diseases, and could be used in agriculture for safe and nature-friendly seed-treatments.

Author Contributions: S.L., N.R. and A.V. conceived and designed the experiments; S.L. performed the experiments; S.L. analyzed the data; N.R. and A.V. contributed reagents/materials/analysis tools; S.L. wrote the paper. All authors have read and agreed to the published version of the manuscript.

Founding: This research received no external funding.

Conflicts of Interest: The authors declare no conflict of interest. The founding sponsors had no role in the design of the study; in the collection, analyses, or interpretation of data; in the writing of the manuscript, and in the decision to publish the results.

\section{Abbreviations}

The following abbreviations are used in this manuscript:

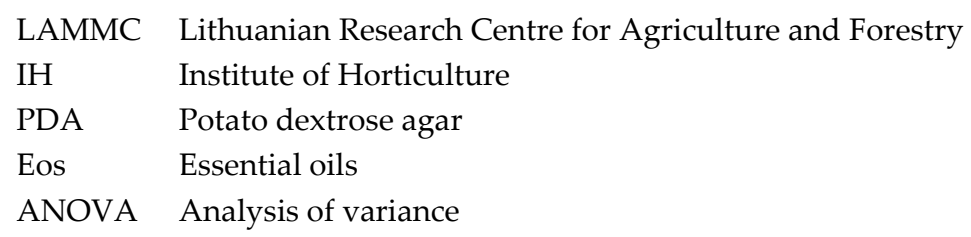

\section{References}

1. Que, F.; Hou, X.; Wang, G.; Xu, Z.; Tan, G.; Li, T.; Wang, Y.; Khadr, A.; Xiong, A. Advances in research on the carrot, an important root vegetable in the Apiaceae family. Hortic. Res. Engl. 2019, 6, 69-82, doi:10.1038/s41438-019-0150-6. Available online: https:/www.nature.com/articles/s41438-019-0150-6 (accessed on 1 November 2020).

2. Michael, T.P.; VanBuren, R. Progress, challenges and the future of crop genomes. Curr. Opin. Plant Biol. 2015, 24, 71-81, doi:10.1016/j.pbi.2015.02.002. Available online: https://pubmed.ncbi.nlm.nih.gov/25703261/(accessed on 1 November 2020).

3. Luby, C.H.; Maeda, H.A.; Goldman, I.L. Genetic and phenological variation of tocochromanol (vitamin E) content in wild (Daucus carota L. var. carota) and domesticated carrot (D. carota L. var. sativa). Hortic. Res. Engl 2014, 1, 14015, doi:10.1038/hortres.2014.15. Available online: https://www.nature.com/articles/hortres201415 (accessed on 1 November 2020).

4. EPPO Standard. PP 2/1 (1) Guideline on good plant protection practice: Umbelliferous crops. Bull. OEPP/EPPO Bull. 1994, 24, 233-240.

5. Zhang, X.; Wang, R.; Ning, H.; Li, W.; Bai, Y.; Li, Y. Evaluation and management of fungal-infected carrot seeds. Sci. Rep. 2020, 10, 1-8, doi:10.1038/s41598-020-67907-5. Available online: https://www.nature.com/articles/s41598-020-67907-5 (accessed on 1 November 2020).

6. Davis, R.M. Carrot diseases and their management. In Diseases of Fruits and Vegetables; Naqvi, S.A.M.H., Ed.; Springer: Dordrecht, The Netherlands, 2004; Volume I, pp. 397-439, doi:10.1007/1-4020-2606-4_10.

7. González, M.; Caetano, P.; Sánchez, M.E. Testing systemic fungicides for control of Phytophthora oak root disease. Forest Pathol. 2017, 47, e12343, doi:10.1111/efp.12343. 
8. Lamichhane, J.R.; You, M.P.; Laudinot, V.; Barbetti, M.J.; Aubertot, J.N. Revisiting sustainability of fungicide seed treatments for field crops. Plant Dis. 2020, 104, 610-623, doi:10.1094/PDIS-06-19-1157-FE. Available online: https://apsjournals.apsnet.org/doi/full/10.1094/PDIS-06-19-1157-FE (accessed on 2 November 2020).

9. Singh, U.B.; Chaurasia, R.; Manzar, N.; Kashyap, A.S.; Malviya, D.; Singh, S.; Kannojia, P.; Sharma, P.K.; Imran, M.; Sharma, A.K. Chemical Management of Seed-Borne Diseases: Achievements and Future Challenges. In Seed-Borne Diseases of Agricultural Crops: Detection, Diagnosis E Management; Kumar, R., Gupta, A., Eds.; Springer: Singapore, 2020; pp. 665-682, doi:10.1007/978-981-32-9046-4_23. Available online: https://link.springer.com/chapter/10.1007/978-981-32-9046-4_23 (accessed on 2 November 2020).

10. Töfoli, J.G.; Domingues, R.J.; Tortolo, M.P.L. Effect of various fungicides in the control of Alternaria Leaf Blight in carrot crops. Biológico São Paulo 2019, 81, 1-30, doi:10.1094/PDIS.2001.85.11.1149. Available online: https://www.researchgate.net/publication/240595009_Optimization_of_Chemical_Suppression_of_Altern aria_dauci_the_Causal_Agent_of_Alternaria_Leaf_Blight_in_Carrots (accessed on 2 November 2020).

11. Silva, V.; Mol, H.G.; Zomer, P.; Tienstra, M.; Ritsema, C.J.; Geissen, V. Pesticide residues in European agricultural soils-A hidden reality unfolded. Sci. Total Environ. 2019, 653, 1532-1545, doi:10.1016/j.scitotenv.2018.10.441. Available online: https://www.sciencedirect.com/science/article/pii/S0048969718343420 (accessed on 2 November 2020).

12. Cozma, P.; Apostol, L.C.; Hlihor, R.M.; Simion, I.M.; Gavrilescu, M. Overview of human health hazards posed by pesticides in plant products. In Proceedings of the 2017 E-Health and Bioengineering Conference (EHB), Sinaia, Romania, 22-24 June 2017; IEEE: Piscataway, NJ, USA, 2017; Volume 17066084, pp. 293-296, doi:10.1109/EHB.2017.7995419.

13. Valdivieso-Ugarte, M.; Gomez-Llorente, C.; Plaza-Díaz, J.; Gil, Á. Antimicrobial, antioxidant, and immunomodulatory properties of essential oils: A systematic review. Nutrients 2019, 11, 2786, doi:10.3390/nu11112786. Available online: https://www.mdpi.com/2072-6643/11/11/2786/htm (accessed on 3 November 2020).

14. Moulodi, F.; Khezerlou, A.; Zolfaghari, H.; Mohamadzadeh, A.; Alimoradi, F. Chemical Composition and Antioxidant and Antimicrobial Properties of the Essential Oil of Hyssopus officinalis L. J. Kermanshah Univ. Med Sci. 2018, 22, doi:10.5812/jkums.85256. Available online: https://sites.kowsarpub.com/jkums/articles/85256.html (accessed on 4 November 2020).

15. Ložienė, K.; Venskutonis, P.R. Juniper (Juniperus communis L.) oils. In Essential Oils in Food Preservation, Flavor and Safety; Academic Press: Cambridge, MA, USA, 2016; pp. 495-500, doi:10.1016/B978-0-12-4166417.00056-0.

16. Dauqan, E.M.; Abdullah, A. Medicinal and functional values of thyme (Thymus vulgaris L.) herb. J. Appl. Biol. Biotechnol. 2017, 5, 17-22, doi:10.7324/JABB.2017.50203. Available online: https://www.jabonline.in/admin/php/uploads/188_pdf.pdf (accessed on 4 November 2020).

17. Karaca, G.; Bilginturan, M.; Olgunsoy, P. Effects of some plant essential oils against fungi on wheat seeds. Indian J. Pharm. Educ. Res. 2017, 51, S385-S388, doi:10.5530/ijper.51.3s.53. Available online: https://www.researchgate.net/publication/320248647_Effects_of_Some_Plant_Essential_Oils_against_Fun gi_on_Wheat_Seeds (accessed on 5 November 2020).

18. Muthukumar, A.; Sangeetha, G.; Naveenkumar, R. Antimicrobial activity of essential oils against seed borne fungi of rice (Oryza sativa L.). J. Environ. Biol. 2016, 37, 1429-1436. Available online: https://www.researchgate.net/publication/316015862_Antimicrobial_activity_of_essential_oils_against_se ed_borne_fungi_of_rice_Oryza_sativa_L (accessed on 4 November 2020).

19. AOAC. Volatile oil in spices. In Official Methods of Analysis, 15th ed.; Helrich, K., Ed.; Association of Official Analytical Chemists: Washington, DC, USA, 1990; Volume 1.

20. Acumedia. A Subsidiary of NEOGEN Corporation. Neogen Food Safety. Potato Dextrose Agar (7149)Protocol. PI7149 Rev 4, 2011.

21. Mathur, S.B.; Kongsdal, O. Common Laboratory Seed Health Testing Methods for Detecting Fungi, 1st ed.; International Seed Testing Association: Bassersdorf, Switzerland, 2003; 425p, ISBN 3906549356.

22. Mancini, V.; Murolo, S.; Romanazzi, G. Diagnostic methods for detecting fungal pathogens on vegetable seeds. Plant Pathol. 2016, 65, 691-703, doi:10.1111/ppa.12515. Available online: https://bsppjournals.onlinelibrary.wiley.com/doi/pdf/10.1111/ppa.12515 (accessed on 5 November 2020). 
23. Mamgain, A.; Roychowdhury, R.; Tah, J. Alternaria pathogenicity and its strategic controls. Res. J. Biol. 2013, 1, 1-9. Available online: https://www.rroij.com/open-access/alternaria-pathogenicity-and-itsstrategic-controls -.php?aid=35925 (accessed on 5 November 2020).

24. Soković, M.D.; Vukojević, J.; Marin, P.D.; Brkić, D.D.; Vajs, V.; van Griensven, L.J.L.D. Chemical composition of essential oils of Thymus and Mentha species and their antifungal activities. Molecules 2009, 14, 238-249, doi:10.3390/molecules14010238. Available online: https://www.ncbi.nlm.nih.gov/pmc/articles/PMC6253825/(accessed on 6 November 2020).

25. Dorna, H.; Qi, Y.; Szopińska, D. The effect of acetic acid, grapefruit extract and selected essential oils on germination, vigour and health of carrot (Daucus carota L.) seeds. Acta Sci. Polonorum. Hortorum Cultus 2018, 17, 27-38, doi:10.24326/asphc.2018.2.3. Available online: http://www.hortorumcultus.actapol.net/pub/17_2_27.pdf (accessed on 6 November 2020).

26. Vokou, D.; Chalkos, D.; Karamanlidou, G.; Yiangou, M. Activation of soil respiration and shift of the microbial population balance in soil as a response to Lavandula stoechas essential oil. J. Chem. Ecol. 2002, 28, 755-768, doi:10.1023/A:1015236709767. Available online: https://www.researchgate.net/(accessed on 7 November 2020).

27. Koch, E.; Schmitt, A.; Stephan, D.; Kromphardt, C.; Jahn, M.; Krauthausen, H.J.; Forsberg, G.; Werner, S.; Amein, T.; Wright, S.A.I.; et al. Evaluation of non-chemical seed treatment methods for the control of Alternaria dauci and A. radicina on carrot seeds. Eur. J. Plant Pathol. 2010, 127, 99-112, doi:10.1007/s10658009-9575-3. Available online: https://link.springer.com/article/10.1007/s10658-009-9575-3 (accessed on 8 November 2020).

28. Riccioni, L.; Orzali, L. Activity of tea tree (Melaleuca alternifolia, Cheel) and thyme (Thymus vulgaris, Linnaeus.) essential oils against some pathogenic seed borne fungi. J. Essent. Oil Res. 2011, 23, 43-47, doi:10.1080/10412905.2011.9712280. Available online: http.tandfonline.com/doi/abs/10.1080/10412905.2011.9712280 (accessed on 9 November 2020).

29. Zabka, M.; Pavela, R.; Slezakova, L. Antifungal effect of Pimenta dioica essential oil against dangerous pathogenic and toxinogenic fungi. Industrial Crops Prod. 2009, 30, 250-253, doi:10.1016/j.indcrop.2009.04.002.

30. Menghani, E.; Sharma, S.K. Antimicrobial activity of Juniperus communis and Solanum xanthocarpum. Int. J. Pharm. Sci. Res. 2012, 3, 2815, doi:10.13040/IJPSR.0975-8232.3.2815-18. Available online: https://ijpsr.com/bft-article/antimicrobial-activity-of-juniperus-communis-and-solanumxanthocarpum/?view= fulltext (accessed on 9 November 2020).

31. Fraternale, D.; Ricci, D.; Epifano, F.; Curini, M. Composition and antifungal activity of two essential oils of hyssop (Hyssopus officinalis L.). J. Essent. Oil Res. 2004, 16, 617-622, doi:10.1080/10412905.2004.9698810.

32. Judžentienè, A. Hyssop (Hyssopus officinalis L.) Oils. In Essential Oils in Food Preservation, Flavor and Safety; Academic Press: Cambridge, MA, USA; 2016; pp. 471-479, doi:10.1016/B978-0-12-416641-7.00053-5.

Publisher's Note: MDPI stays neutral with regard to jurisdictional claims in published maps and institutional affiliations.

(C) 2020 by the authors; licensee MDPI, Basel, Switzerland. This article is an open access article distributed under the terms and conditions of the Creative Commons by Attribution (CCBY) license (http://creativecommons.org/licenses/by/4.0/). 